P-ISSN: 2774-4574 ; E-ISSN: 2774-4582

TRILOGI, 2(3), September-Desember 2021 (360-374) @2021 Lembaga Penerbitan, Penelitian, dan Pengabdian kepada Masyarakat (LP3M) Universitas Nurul Jadid Paiton Probolinggo

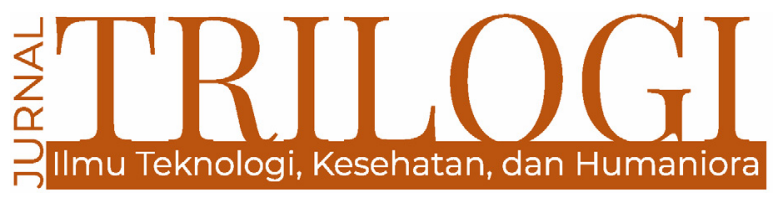

\title{
PEMBUATAN BUKU APLIKASI ELEKTRONIK ZIARAH WALI SONGO BERBASIS MOBILE COMPUTING
}

\section{Bambang}

Universitas Nurul Jadid

bambangb19@gmail.com

\author{
Muhammad Rofiqi \\ Universitas Nurul Jadid \\ muhammadrofiqi02@gmail.com
}

\section{Kifliyanto}

Universitas Nurul Jadid

kyukisiga@gmail.com

\section{Luqman Hakim}

Universitas Nurul Jadid

lukmannur505@gmail.com

\author{
Mohammad Ali Makki \\ Universitas Nurul Jadid \\ Makki6506@gmail.com
}

\author{
Luthfi Fu'ady \\ Universitas Nurul Jadid \\ luthfifuady05@gmail.com
}

\author{
Fanny Brawijaya \\ Universitas Nurul Jadid \\ Fannybrawijaya@gmail.com
}

Mirza Alief Nurzahwa

Universitas Nurul Jadid

mirzaleeef@gmail.com

\begin{abstract}
Walisongo ialah para wali (muballigh) yang telah berjasa besar dalam penyebaran ajaran agama Islam kepada masyarakat di tanah Jawa. Cara berdakwa yang mereka lakukan dengan cara yang arif dan bijaksana membuat ajaran mereka cepat mendapat tempat di hati masyarakat tanah Jawa. Karena banyaknya peziarah yang melakukan ziarah secara terus-menerus, penyedia jasa perjalanan tour Wali Songo semakin meningkat. Namun banyak peziarah yang tidak mengetahui informasi tentang sejarah, tempat, adab dan bacaan-bacaan apa saja yang harus dibaca saat berkunjung ke makam wali. Hal ini dapat membuat kesan yang kurang tepat bagi warga sekitar situs makam Wali Songo terhadap para peziarah yang tidak melaksanakan tradisi yang ada.Atau dengan ini, solusi dari permasalahan diatas, peneliti merasa tertarik untuk membuat "Aplikasi Elektronik Ziarah Wali Songo Berbasis Mobile Computing". Dengan tersedianya aplikasi tersebut para peziarah bisa terbantu dan mengetahui segala informasi tentang tata cara ziarah Wali Songo. Perubahan ini terjadi diantaranya adalah berkat jasa para muballigh dan para wali. Walisongo secara umum yang berarti sembilan orang wali, sedangkan secara filosofis maksudnya sembilan orang yang telah mampu mencapai tingkat wali, Kata "wali" (Arab) antara lain berarti pembela, Bagi orang yang memiliki kesenangan melakukan ziarah ke tempat makam ulama, wali maupun makam tokoh sejarah yang telah memiliki pengaruh kuat di suatu daerah tersebut. Bahkan peziarah seperti ini melakukan ziarah secara terus-menerus dari suatu makam keramat ke makam keramat yang lainnya.Bacaan-bacaan dan adab apa saja yang harus dibaca saat berkunjung ke makam wali.
\end{abstract}


Tujuan dari penelitian ini adalah mengembangkan media informasi tentang ziarah wali songo. Menambah wawasan dan pengetahuan langsung tentang meningkatkan kemampuan dalam pembuatan aplikasi buku elektronik berbasis mobile computing ini. Memberikan informasi lengkap tentang apa saja yang harus dilakukan pada saat di wisata makam wali songo. Dengan adanya aplikasi ini diharapkan dapat memberikan variasi dan kemudahan bagi pihak tour travel dalam peyampaian informasi selain dengan sekedar buku elektronik untuk peziarah sebagai desain system dengan Berbasis Mobile Computing menggunakan Bahasa pemograman Android Studio. Hasil penelitian ini adalah Aplikasi Buku Elektronik Ziarah Wali Songo.

\section{Keywords: mastering, vocabulary, song lyrics}

Tempat wisata Wali songo ialah para wali (muballigh) yang telah berjasa besar dalam penyebaran ajaran agama Islam kepada masyarakat di tanah Jawa. Cara berdakwa yang mereka lakukan dengan cara yang arif dan bijaksana membuat ajaran mereka cepat mendapat tempat di hati masyarakat tanah Jawa. Karena banyaknya peziarah yang melakukan ziarah secara terus-menerus, penyedia jasa perjalanan tour Wali Songo semakin meningkat. Namun banyak peziarah yang tidak mengetahui informasi tentang sejarah, tempat, adab dan bacaan-bacaan apa saja yang harus dibaca saat berkunjung ke makam wali. Hal ini dapat membuat kesan yang kurang tepat bagi warga sekitar situs makam Wali Songo terhadap para peziarah yang tidak melaksanakan tradisi yang ada. Atau dengan ini, solusi dari permasalahan diatas, peneliti merasa tertarik untuk membuat "Aplikasi Elektronik Ziarah Wali Songo Berbasis Mobile Computing". Dengan tersedianya aplikasi tersebut para peziarah bisa terbantu dan mengetahui segala informasi tentang tata cara ziarah Wali Songo. Perubahan ini terjadi diantaranya adalah berkat jasa para muballigh dan para wali. Walisongo secara umum yang berarti sembilan orang wali, sedangkan secara filosofis maksudnya sembilan orang yang telah mampu mencapai tingkat wali, Kata "wali" (Arab) antara lain berarti pembela, Bagi orang yang memiliki kesenangan melakukan ziarah ke tempat makam ulama, wali maupun makam tokoh sejarah yang telah memiliki pengaruh kuat di suatu daerah tersebut. Bahkan peziarah seperti ini melakukan ziarah secara terus-menerus dari suatu makam keramat ke makam keramat yang lainnya. Bacaanbacaan dan adab apa saja yang harus dibaca saat berkunjung ke makam wali. Tujuan dari penelitian ini adalah mengembangkan media informasi tentang ziarah wali songo. Menambah wawasan dan pengetahuan langsung tentang meningkatkan kemampuan dalam pembuatan aplikasi buku elektronik berbasis mobile computing ini.
Memberikan informasi lengkap tentang apa saja yang harus dilakukan pada saat di wisata makam wali songo. Dengan adanya aplikasi ini diharapkan dapat memberikan variasi dan kemudahan bagi pihak tour travel dalam peyampaian informasi selain dengan sekedar buku elektronik untuk peziarah. (UML) sebagai desain system dengan Berbasis Mobile Computing menggunakan Bahasa pemograman Android Studio. Hasil penelitian ini adalah Aplikasi Buku Elektronik Ziarah Wali Songo.

\section{Pendahuluan}

Wali songo adalah para wali (muballigh) yang telah berjasa besar dalam penyebaran ajaran agama Islam kepada masyarakat di tanah Jawa Cara berdakwa mereka yang dilakukan dengan cara yang arif dan bijaksana membuat ajaran yang mereka bawa cepat mendapat tempat di hati masyarakat tanah Jawa. Era Wali songo adalah era berakhirnya dominasi Hindu-Budha dalam budaya Nusantara untuk digantikan dengan kebudayaan Islam. Mereka adalah simbol penyebaran Islam di Indonesia, khususnya di tanah Jawa (Kholid, 2016).

Tulisan ini akan membahas tentang wali songo, eksistensi dan fungsinya dalam proses Islamisasi serta implikasinya terhadap munculnya berbagai tradisi yang ada di tanah Jawa yang dianggap sebagai akibat adanya proses Islamisasi yang dilakukan oleh para wali songo dengan cara-cara yang arif dan bijaksana tanpa adanya kekerasan dan penghancuran terhadap tradisi dan kebudayaan masa sebelum datangnya Islam di tanah Jawa.

Sebelum masuknya Islam ke Pulau Jawa, pada umumnya situasi masyarakatnya cenderung dipengaruhi oleh adanya sistem kasta dalam.agama Hindu atau dikenal dengan perbedaan golongan kelas, sehingga kehidupan masyarakatnya bertingkat-tingkat dan terkotakkotak. Mereka yang kastanya lebih tinggi tidak 
boleh bergaul dengan orang yang berkasta lebih rendah dan seterusnya. Masyarakat Hindu ketika itu membagi kastanya menjadi empat kasta yaitu: kasta brahmana, kasta ksatria, kasta waisya, dan kasta sudra. Sebagai kasta yang paling rendah, kasta sudra sering tertindas oleh kasta lainnya, sehingga kehidupannya selalu diliputi keresahan. Setelah ajaran Islam masuk dan tersebar din tengah-tengah masyarakat, susunan masyarakat berdasarkan kasta ini terkikis perlahan-lahan dan dimulailah suatu kehidupan masyarakat baru tanpa penindasan atas hak asasi manusia yang dilatari oleh perbedaan tersebut. Perubahan ini terjadi diantaranya adalah berkat jasa para muballigh dan para wali.

Walisongo secara sederhana artinya sembilan orang wali, sedangkan secara filosofis maksudnya sembilan orang yang telah mampu mencapai tingkat wali, suatu derajat tingkat tinggi yang mampu mengawal babahan hawa sanga (mengawal sembilan lubang dalam diri manusia), sehingga memiliki peringkat wali.6 Di dalam Ensiklopedi Islam disebutkan bahwa walisongo (sembilan wali) adalah sembilan ulama yang merupakanb pelopor dan pejuang pengembangan Islam (islamisasi) di Pulau Jawa pada abad kelima belas (masa Kesultanan Demak). Kata "wali" (Arab) antara lain berarti pembela, teman dekat dan pemimpin. Dalam pemakaiannya, wali biasanya diartikan sebagai orang yangm dekat dengan Allah (Waliyullah). Sedangkan kata "songo" (Jawa) berarti sembilan. Maka walisongo secara umum diartikan sebagai sembilan wali yang dianggap telah dekat dengan Allah SWT, terus menerus beribadah kepada-Nya, serta memiliki kekeramatan dan kemampuan lain di luar kebiasaan manusia (Sultoni, 2016).

Ziarah biasanya dilakukan dengan cara seseorang pergi berkunjung ke suatu makam dimana makam tersebut merupakan makam orang-orang besar yang dihormati.

Di Indonesia, khususnya di pulau jawa terdapat makam-makam yang dianggap keramat. Keramat disini, mempunyai arti bahwa makam tersebut merupakan makam seorang waliyullah. Salah satu tokoh sejarah, yang berjasa menyebarkan agama islam dipulau jawa adalah Wali Songo. Karena itulah, makam-makam mereka termasuk dalam makam keramat yang keramat.

Bagi orang yang memiliki kesenangan melakukan ziarah ke tempat-tempat yang mereka anggap sebagai makam ulama, wali maupun makam tokoh sejarah yang telah memiliki pengaruh kuat di suatu daerah. Bahkan peziarah seperti ini melakukan ziarah secara berantai dari suatu makam keramat ke makam keramat yang lainnya.

Karena banyaknya peziarah yang ingin melakukan ziarah secara terus-menerus, penyedia jasa perjalanan tour Wali Songo semakin meningkat. Namun banyak peziarah yang tidak mengetahui informasi tentang sejarah, tempat, adab dan bacaan-bacaan apa saja yang harus dibaca saat berkunjung ke makam wali. Hal ini membuat kesan yang kurang baik bagi warga sekitar situs makam Wali Songo terhadap para peziarah yang tidak melaksanakan tradisi yang ada.

\subsection{Studi Pustaka}

\section{A. Penelitian Terkait}

Penelitian terkait yang ketiga yang dilakukan oleh Miftahul Khoiri, Martinus Wednas Mahendra, M.Ghofar Rohman (2017) dengan judul "Sistem Informasi Geografis Wali Songo Berbasis Android" Aplikasi sistem informasi geografis Wali Songo berbasis android ini dibuat dengan tujuan untuk mengetahui letak geografis Makam Wali Songo di Pulau Jawa, aplikasi ini dibuat karena selama ini masyarakat sering dibuat bingung dengan letak geografis atau lokasi Makam Wali Songo, dikarenakan smartphone semakin berkembang, maka dibuat aplikasi GIS atau SIG, agar masyarakat lebih mudah dalam mencari jalur lokasi Makam Wali Songo. Pembuatan aplikasi ini atau GIS ini menggunkan metode penelitian dan pengembangan. Langkah yang dilakukan meliputi. analisa kebutuhan sistem, analisa sepesifikasi sistem, tahapan desain, implementasi, unit testing, pemeliharaan. Teknik pengumpulan data yang penulis lakukan dari beberapa buku dan jurnal. Aplikasi ini juga memanfaatkan android dan Google Maps. Sistem informasi dan geografis Wali Songo ini dapat digunakan sebagai alternatif media petunjuk arah para peziarah Wali Songo yang tidak mengetahui sejarah maupun rute menuju Makam Wali Songo, dalam aplikasi ini terdapat. informasi sejarah dan rute Makam Wali Songo (Miftahul Khoiri, 2017).

\section{B. Buku Saku}

Buku saku adalah buku yang berukuran kecil sehingga dapat dimasukkan ke dalam 
saku dan mudah dibawa kemana-mana. Sebagian besar orang menyebut buku kecil sebagai buku saku karena biasanya dapat dimasukkan ke dalam saku tanpa harus membutuhkan tempat yang luas. Sehingga dapat dikatakan bahwa buku saku merupakan istilah dari buku yang berukuran kecil. "buku saku diartikan buku dengan ukurannya yang kecil, ringan, dan bisa disimpan di saku, sehingga praktis untuk kapan saja bisa dibaca. buku saku merupakan buku sehingga efektif untuk dapat dibaca kapan saja pada saat dibutuhkan (Windiarti, 2016)..

\section{Android}

Menurut Nasruddin Safaat h (Pemrograman aplikasi mobile smartphone dan tablet PC berbasis android) android adalah sebuah sistem operasi pada handphone yang bersifat terbuka dan berbasis pada sistem operasi Linux. Android bisa digunakan oleh setiap orang yang ingin menggunakannya pada perangkat mereka. Android menyediakan platform terbuka bagi para pengembang untuk menciptakan aplikasi mereka sendiri yang akan digunakan untuk bermacam peranti bergerak (Sulihati, 2016).

\section{Android Studio}

Android Studio adalah sebuah IDE yang bisa digunakan untuk pengem bangan aplikasi Android, dan dikembangkan oleh google. Android Studio merupakan pengembangan dari Eclipse IDE, dan dibuat berdasarkan IDE Java populer, yaitu Intelli] IDEA. Android Studio Di rencanakan untuk menggantikan Eclipse ke depannya sebagai IDE resmi untuk pengembangan aplikasi Android. Sebagai Pengembangan dari Eclipse Android Studio mempunyai banyak fitur-fitur baru dibandingkan dengan Eclipse IDE. Berbeda dengan Eclipse yang menggunakan ADT, Android Studio Menggunakan gradle sebagai build environment. Fitur-fitur lainnya adalah sebagai berikut: (Astrid A. A. Makiolor, 2017).

1) Menggunakan Gradle-based build system yang fleksibel.

2) Bisa mem-build multiple APK.

3) Template support untuk Google Service dan

4) berbagai macam tipe perangkat.

5) Layout editor yang lebih bagus.

\section{E. UML}

UML (Unified Modelling Language) adalah salah satu alat bantu yang sangat handal di dunia pengembangan sistem yang berorientasi obyek. Hal ini disebabkan karena UML menyediakan bahasa pemodelan visual yang memungkinkan bagi pengembangan sistem untuk membuat cetak biru atas visi mereka dalam bentuk yang baku, mudah dimengerti serta dilengkapi dengan mekanisme yang efektif untuk berbagi dan mengkomunikasikan rancangan mereka dengan yang lain (Harni Kusniyati, 2016).

\section{F. Use Case Diagram}

Use case adalah deskripsi fungsi dari sebuah sistem dari perspektif pungguna. Use case bekerja dengan cara deskripsikan tipikal interaksi pada antar user (pengguna) sebuah sistem dengan sistemnya sendiri melalui sebuah cerita bagaimana sebuah system dipakai (Harni Kusniyati, 2016).

\subsection{Rancangan Penelitian}

Rancangan penelitian merupakan suatu proses dari perencanaan dan pelaksanaan penelitian. Rancangan penelitian bertujuan agar penelitian bisa berjalan dengan lancar sesuai dengan rencana dan tujuan yang di harapkan. Jenis penelitian yang digunakan dalam penelitian yang ini adalah metode kuantatif

Rancangan penelitian ini adalah penelitian dan buku elektronik. Dalam penelitian dan pengembangan buku elektronik ini menggunakan metode UML(Unified Modelling Language) adalah salah satu alat bantu yang sangat handaldi dunia pengembangan sistem yang berorientasi obyek. Hal ini disebabkan karena UML menyediakan bahasa pemodelan visualyang memungkinkan bagi pengembangan sistem untuk membuat cetak biru atas visi mereka dalam bentuk yang baku, mudah di mengerti serta di lengkapi dengan mekanisme yang efektif untuk berbagi dan mengkomunikasikan rancangan mereka dengan yang lain Munawar menyatakan bahwa use case adalah deskripsi fungsi dari sebuah sistem dari perspektif pungguna. Usecase bekerja dengan cara deskripsikan tipikalin teraksi pada antar user (pengguna) sebuah sistem dengan sistemnya sendiri melalui sebuah cerita bagaimana sebuah system dipakai Activity diagram adalah teknik untuk mendeskripsikan logika prosedural, proses 
bisnis dan aliran kerja dalam banyak kasus. Activity diagram mempunyai peran sepertihalnya flowchart, akan tetapi perbedaannya dengan flowchart adalah activity diagram biasmen dukung perilaku paralel sedangkan flowchart tidak bias Diagram sequence merupakan salah satuyang menjelaskan bagaimana suatu operasi itu dilakukan message (pesan) apa yang dikirim dan kapan pelaksanaannya (Harni Kusniyati, 2016).

\section{Gambar 1.1}

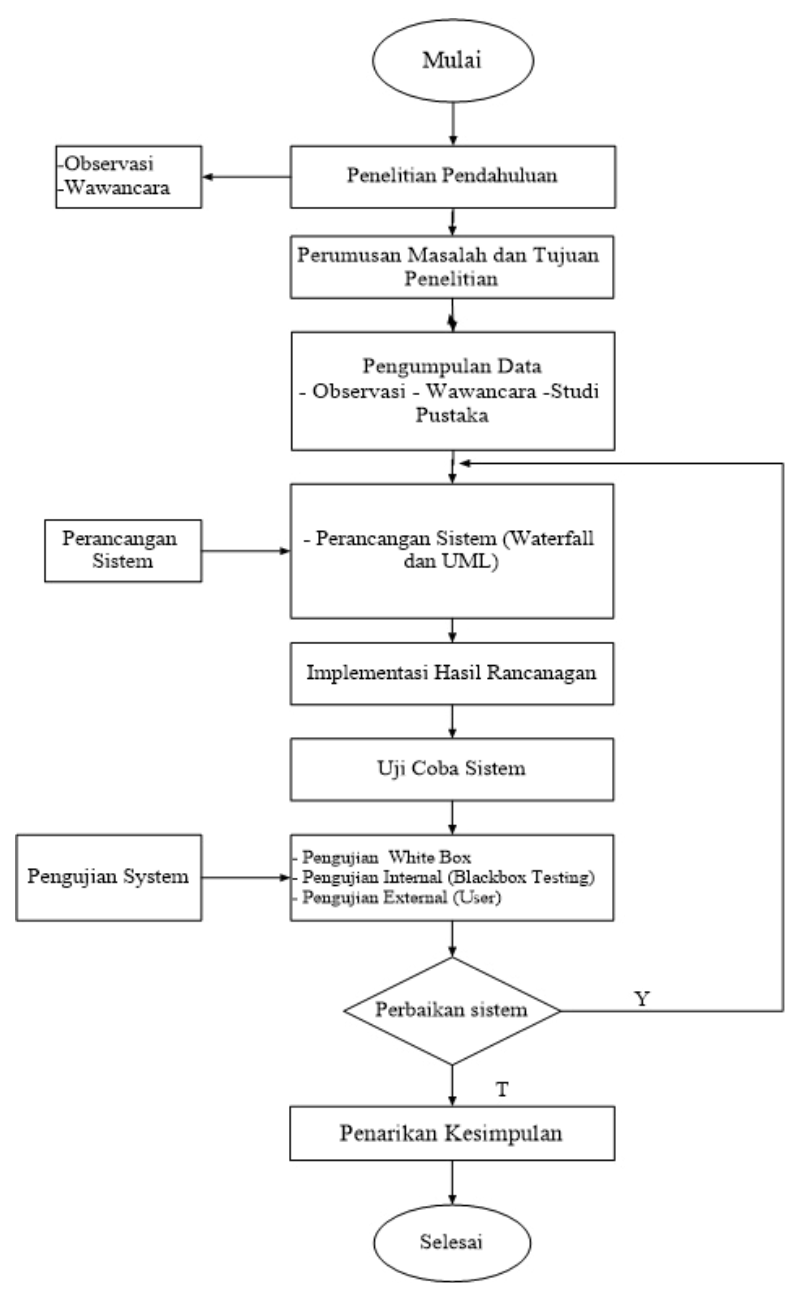

Gambar 1.1 Bagan Perancangan

Untuk mencapai tujuan yang diharapkan, pada penelitian ini digunakan model pengembangan Waterfall. Model pengembangan Waterfall digunakan karena kesederhanaan pada setiap tahapannya sehingga prosedur pengembangan sistem yang akan dibuat menjadi lebih jelas setiap tahapnya. Adapun alur dari model pengembangan tersebut tersebut ditunjukkan pada Gambar

\section{Gambar 1.2}

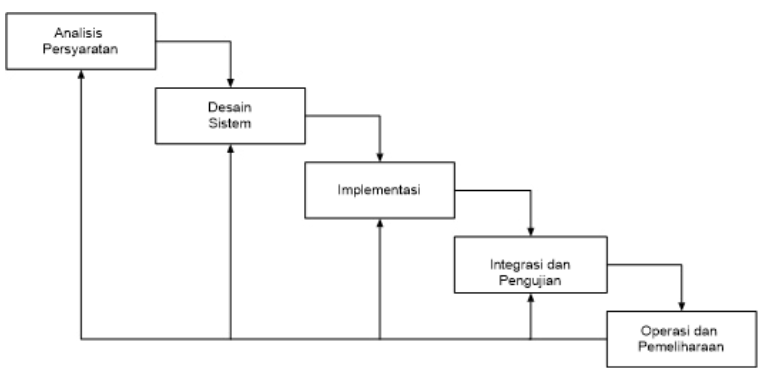

Gambar 1.2 Model Pengembangan Waterfall

\section{Desain}

Tahap desain sistem merupakan tahap yang dilakukan setelah tahap analisis sistem selesai dilakukan. Metode pengembangan yang digunakan adalah Metode Waterfall, dimana setiap tahap harus diselesaikan terlebih dahulu sebelum dilanjutkan ke tahap berikutnya untuk menghindari terjadinya pengulangan tahapan. Adapun tahapan desain pada aplikasi Berbasis Android Buku elektronik meliputi UML, Use Case Diagram, Activity Diagram, Square Diagram. .

Tahap ini dilakukan sebelum melakukan coding. Tahap ini bertujuan untuk memberikan gambaran apa yang seharusnya dikerjakan dan bagaimana tampilannya. Tahap ini membantu dalam menspesifikasikan kebutuhan hardware dan sistem serta mendefinisikan arsitektur sistem secara keseIuruhan (Safitri \& Supriyadi, 2015).

\section{Implementasi}

Dalam tahap ini dilakukan pemrograman. Pembuatan software dipecah menjadi modulmodul kecil yang nantinya akan digabungkan dalam tahap berikutnya. Selain itu dalam tahap ini juga dilakukan pemeriksaaan terhadap modul yang dibuat, apakah sudah memenuhi fungsi yang diinginkan atau belum (Supriyadi, 2015).

\section{Pengujian}

Di tahap ini dilakukan penggabungan modul-modul yang sudah dibuat dan dilakukan pengujian ini dilakukan untuk mengetahui apakah software yang dibuat telah sesuai dengan desainnya dan masih terdapat kesalahan atau tidak (Supriyadi, 2015). untuk pengujian software dalam pengujian ini menggunakan white box testing, black box testing dan pungujian External. 


\section{a. Pengujian White Box}

White Box testing berfokus pada logika dan stuktur internal kode. White Box Testing adalah salah satu cara untuk menguji suatu aplikasi atau software dengan cara melihat modul untuk dapat meneliti dan menganalisa kode dari program yang di buat ada yang salah atau tidak. Kalau modul yang telah dan sudah di hasilkan berupa output yang tidak sesuai dengan yang di harapkan maka akan dikompilasi ulang dan di cek kembali kodekode tersebut hingga sesuai dengan yang diharapkan Pengujian seluruh keputusan yang menggunakan logikal. Pengujian keseluruh loop yang ada sesuai batasan-batasannya. Pengujian pada struktur data yang sifatnya internal dan yang terjamin validitasnya. membuat test case untuk mencari kesalahan/ eror sampai kepada detail pennggecekan kode program (Hendra Rahmadi, 2015).

\section{a. Pengujian Internal (blackbox testing)}

Pengujian black box adalah pengujian aspek funda mental system tanpa memperhatikan struktur logika internal perangkat lunak.Hal ini digunakan untuk mengetahui apakah perangkat lunak berfungsi dengan benar. Data uji dieksekusi pada perangkat lunak dan kemudian keluaran dari perangkat lunak di cek apakah telah sesuai dengan yang diharapkan, pengujian black box berusaha menemukan semua kesalahan. Dalam pengujian perangkat lunak penulis berencana menggunakan metode pengujian black box.Dimana pengujian black box berfokus pada persyaratan fungsional perangkat lunak yang dibuat.

\section{b. Pengujian External (User)}

Pada pengujian external yang dilakukan untuk menguji langsung terhadap pengguna, Penelitian menggunakan perhitungan kuesioner dengan skalali kert yang digunakan untuk mengukur persepsi, sikap atau pendapat pengguna aplikasi yang dapat di aplikasikan dalam angket dan sering digunakan untuk riset yang berupa survei. Pada Pengujian Aplikasi system buku elektronik 4 tipe user menggunakan metode forward chaining berbasis android ini dilakukan pengujian kepada 10 user atau pengguna didapatkan.

Untuk menghasilkan data nilai, pengujian dilakukan dengan menggunakan angket. Adapun langkah-langkahnya sebagai berikut: a) Perolehan skor $=\Sigma$ skor responden

b) Skor hasil pengumpulan data $=\Sigma$ skor perolehan

c) Jumlah skor ideal = skor tertinggi $\mathrm{x}$ jumlah butir soal $x$ jumlah responden

d) Sehingga diperoleh rumus

$$
p=\left(\frac{\text { skor perolehan }}{\text { skor ideal }}\right) \times 100 \%
$$

Gambar 1.3 Rumus Penentuan Skor

\section{Pemeliharaan}

Pemeliharaan merupakan tahap terakhir dalam model waterfall. Software yang sudah jadi dijalankan serta dilakukan pemeliharaan. Pemeliharaan termasuk dalam memperbaiki kesalahan yang tidak ditemukan pada langkah sebelumnya. Perbaikan implementasi unit sistem dan peningkatan jasa system sebagai kebutuhan baru (Supriyadi, 2015).

\section{Hasil Penelitian}

\section{A. Desain Input Output \\ a. Tampilan Halaman Utama}

Tampilan halaman utama adalah tampilan yang akan muncul jika keluar menu Pada tampilan ini terdapat 4 tombol diantaranya Sejarah, Surat Yasin, Tahlil Dan Do'a, Lokasi wali songo, dan Keluar.

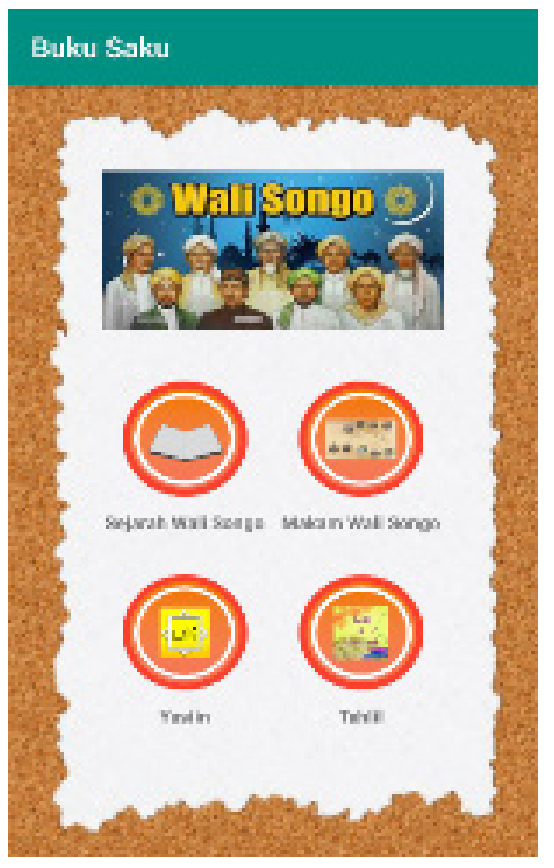

Gambar 2.1 Tampilan Halaman Utama 


\section{b. Tampilan Halaman Utama ke 2}

Tampilan halaman utama adalah tampilan yang akan muncul jika keluar menu Pada tampilan ini terdapat 9 tombol diantaranya sunan ampel, sunan gresik, sunan bonang, sunan drajat, sunan giri, sunan muria, sunan kudus, sunan kalijaga, sunan gunungjati.

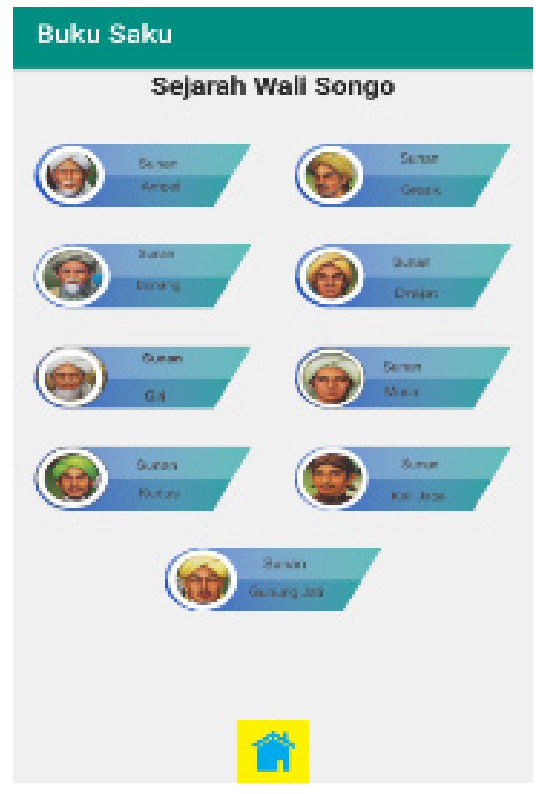

Gambar 2.2 Tampilan Halaman Utama ke 2

\section{c. Tampilan Halaman Sejarah}

Tampilan halaman Sejarah merupakan tampilan yang digunakan untuk tampilan Sejarah. Pada tampilan Sejarah terdapat beberapa tombol penjelasan tentang Ziarah wali songo .

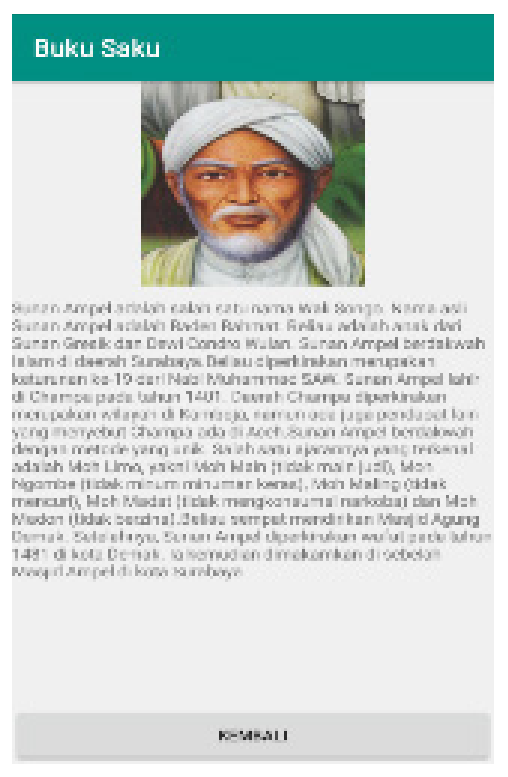

Gambar 2.3 Tampilan Halaman Sejarah

\section{d. Tampilan Halaman Sejarah2}

Tampilan halaman Sejarah merupakan tampilan yang digunakan untuk tampilan Sejarah. Pada tampilan Sejarah terdapat beberapa tombol penjelasan tentang Ziarah wali songo.

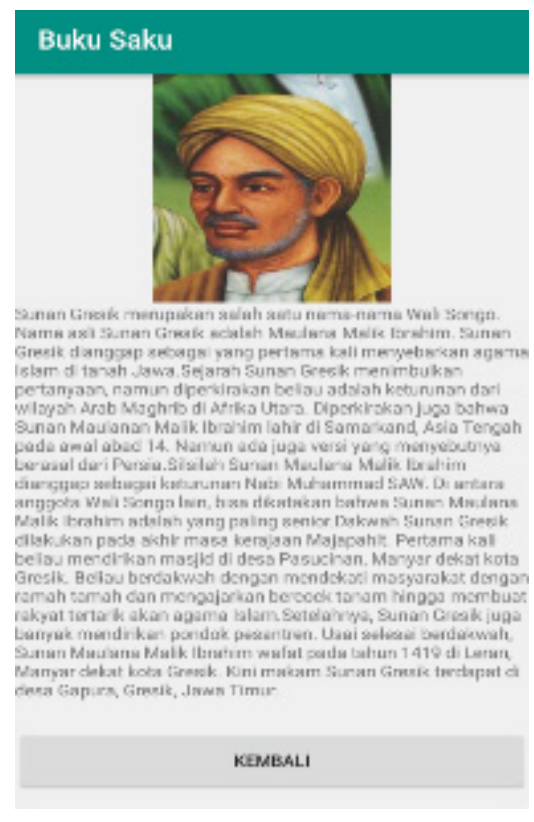

Gambar 2.4 Tampilan Halaman Sejarah2

\section{e. Tampilan Halaman Sejarah3}

Tampilan halaman Sejarah merupakan tampilan yang digunakan untuk tampilan Sejarah. Pada tampilan Sejarah terdapat beberapa tombol penjelasan tentang Ziarah wali songo.

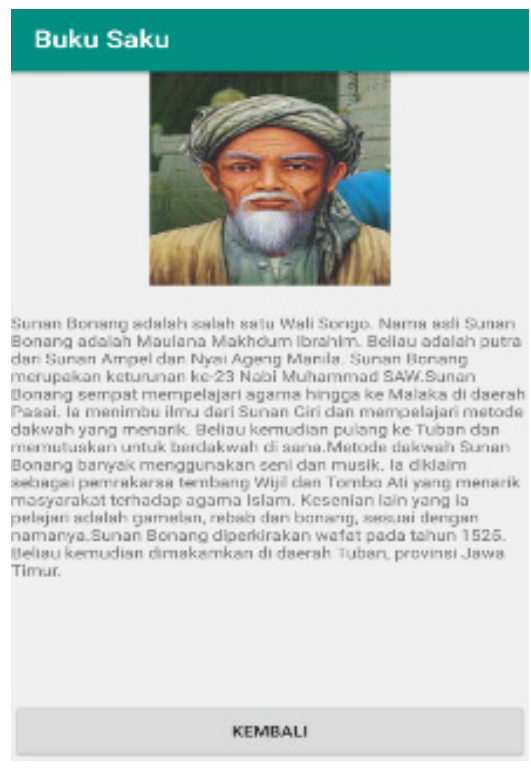

Gambar 2.5 Tampilan Halaman Sejarah3 


\section{f. Tampilan Halaman Sejarah4}

Tampilan halaman Sejarah merupakan tampilan yang digunakan untuk tampilan Sejarah. Pada tampilan Sejarah terdapat beberapa tombol penjelasan tentang Ziarah wali songo .

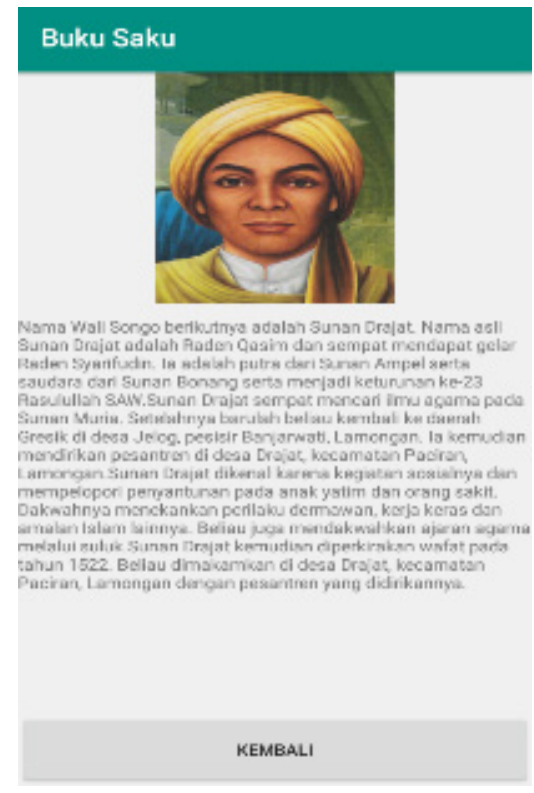

Gambar 2.6 Tampilan Halaman Sejarah4

\section{g. Tampilan Halaman Sejarah5}

Tampilan halaman Sejarah merupakan tampilan yang digunakan untuk tampilan Sejarah. Pada tampilan Sejarah terdapat beberapa tombol penjelasan tentang Ziarah wali songo.

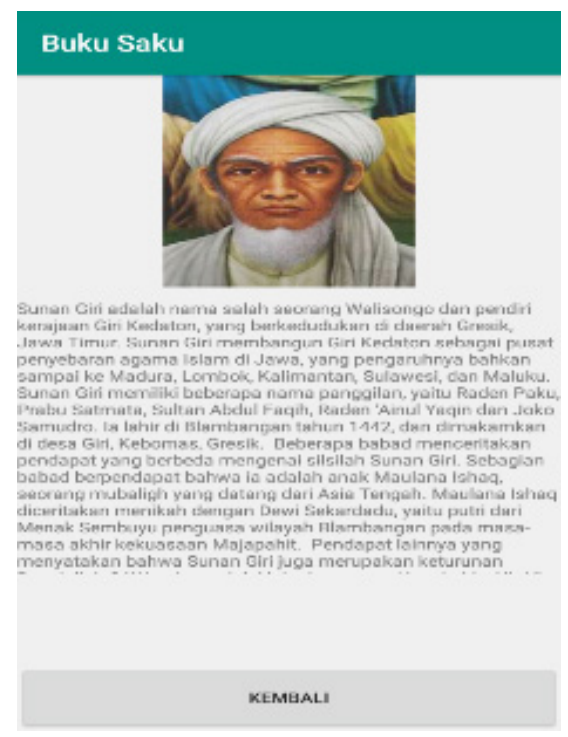

Gambar 2.7 Tampilan Halaman Sejarah5

\section{h. Tampilan Halaman Sejarah6}

Tampilan halaman Sejarah merupakan tampilan yang digunakan untuk tampilan Sejarah. Pada tampilan Sejarah terdapat beberapa tombol penjelasan tentang Ziarah wali songo.

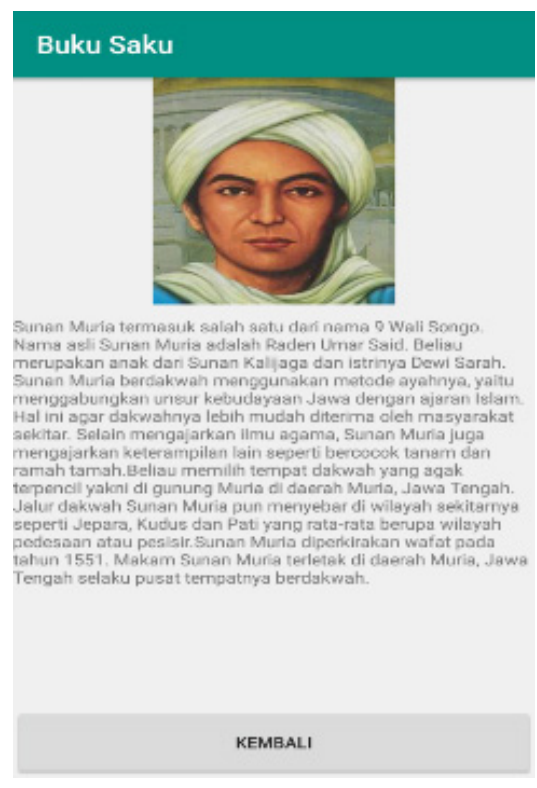

Gambar 2.8 Tampilan Halaman Sejarah6

\section{i. Tampilan Halaman Sejarah7}

Tampilan halaman Sejarah merupakan tampilan yang digunakan untuk tampilan Sejarah. Pada tampilan Sejarah terdapat beberapa tombol penjelasan tentang Ziarah wali songo .

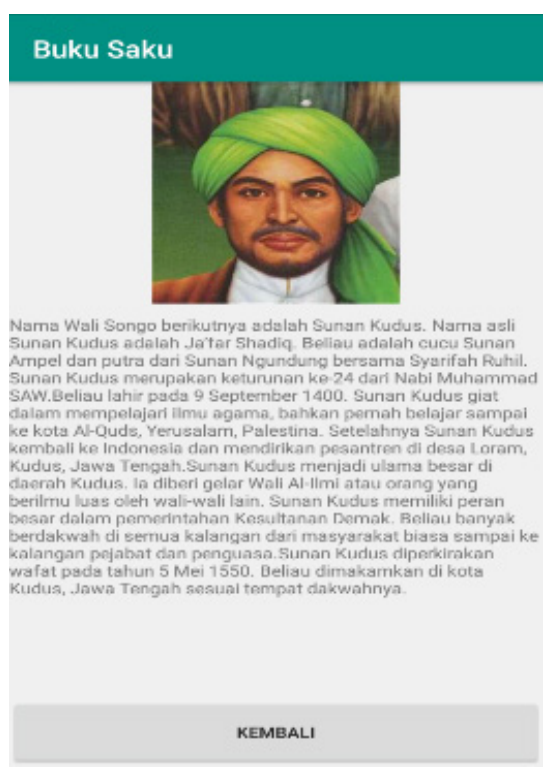

Gambar 2.9 Tampilan Halaman Sejarah7 


\section{j. Tampilan Halaman Sejarah8}

Tampilan halaman Sejarah merupakan tampilan yang digunakan untuk tampilan Sejarah. Pada tampilan Sejarah terdapat beberapa tombol penjelasan tentang Ziarah wali songo.

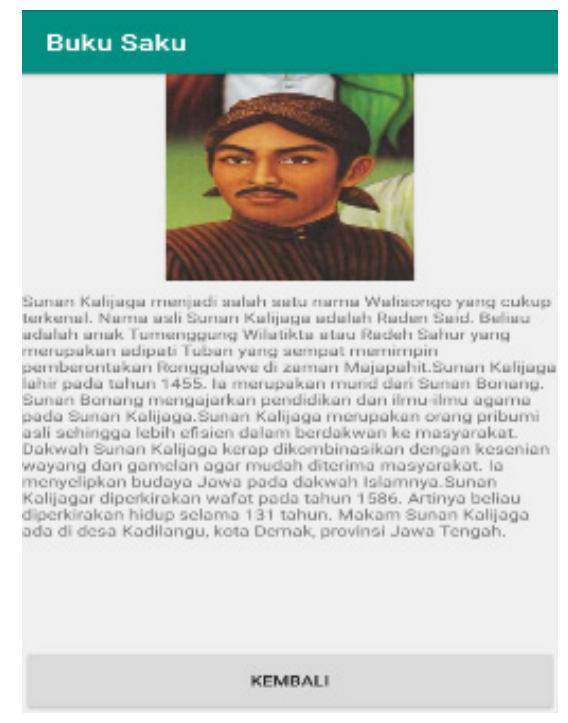

Gambar 2.10 Tampilan Halaman Sejarah8

\section{k. Tampilan Halaman Sejarah9}

Tampilan halaman Sejarah merupakan tampilan yang digunakan untuk tampilan Sejarah. Pada tampilan Sejarah terdapat beberapa tombol penjelasan tentang Ziarah wali songo.

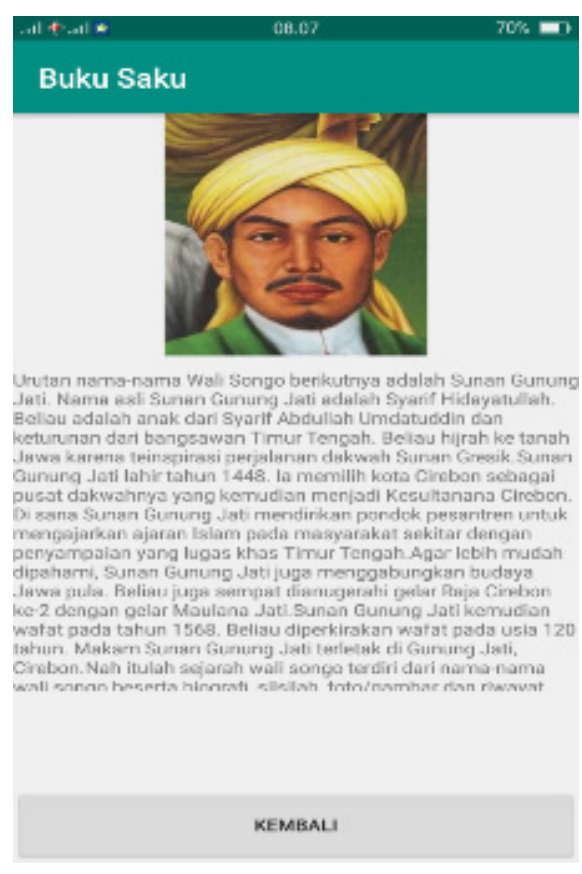

Gambar 2.11 Tampilan Halaman Sejarah9

\section{Tampilan Halaman Surat Yasin}

Tampilan halaman Surat yasin merupakan tampilan yang digunakan untuk tampilan Bacaan. Pada tampilan terdapat 1 tombol penjelasan tentang Surat yasin atau Bacaan.

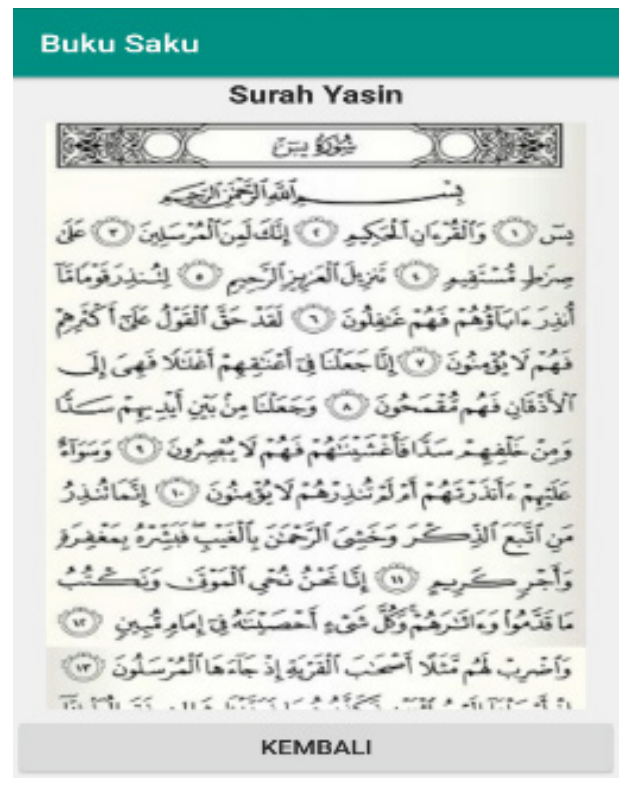

Gambar 2.12 Tampilan Halaman Surat yasin

\section{m. Tampilan Halaman Tahli Dan Do'a}

Tampilan halaman Tahlil Dan Do'a merupakan tampilan yang digunakan untuk tampilan Tahlil Dan. Do'a. Pada tampilan Tahlil Dan Do'a terdapat 1 tombol penjelasan tentang Tahlil Dan Do'a.

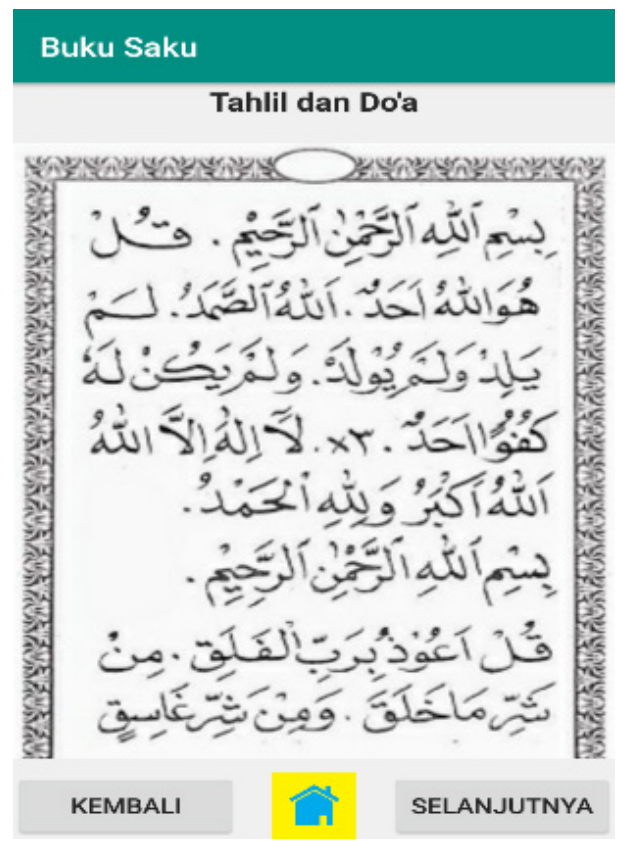

Gambar 2.13 Tampilan Halaman Tahlil Dan Do'a 


\section{n. Tampilan Halaman Tahli Dan Do'a2}

Tampilan halaman Tahlil Dan Do'a merupakan tampilan yang digunakan untuk tampilan Tahlil Dan. Do'a. Pada tampilan Tahlil Dan Do'a terdapat 1 tombol penjelasan tentang Tahlil Dan Do'a.

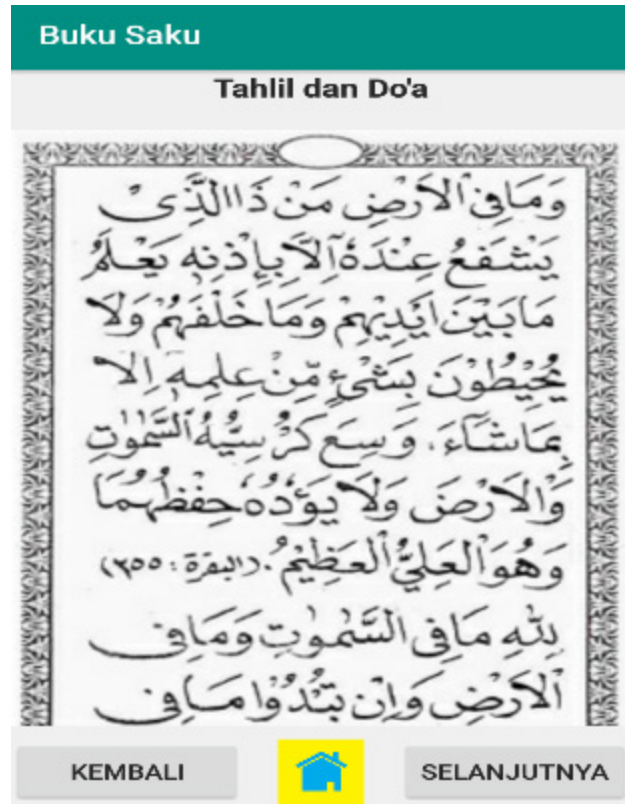

Gambar 2.14Tampilan Halaman Tahlil Dan Do'a

\section{o. Tampilan Halaman Tahlil Dan Do'a2}

Tampilan halaman Tahlil Dan Do'a merupakan tampilan yang digunakan untuk tampilan Tahlil Dan. Do'a. Pada tampilan Tahlil Dan Do'a terdapat 1 tombol penjelasan tentang Tahlil Dan Do'a.

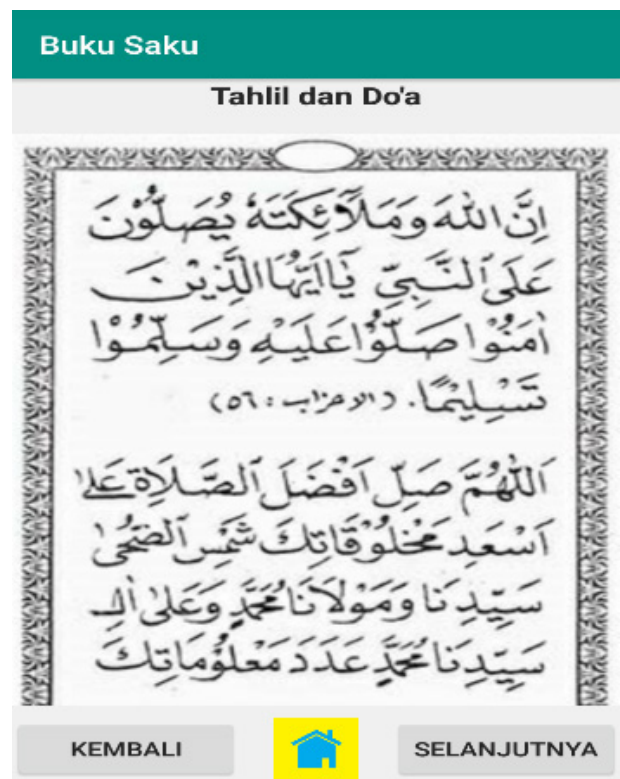

Gambar 2.15 Tampilan Halaman Tahlil Dan Do'a

\section{p. Tampilan Halaman Tahlil Dan Do'a2}

Tampilan halaman Tahlil Dan Do'a merupakan tampilan yang digunakan untuk tampilan Tahlil Dan. Do'a. Pada tampilan Tahlil Dan Do'a terdapat 1 tombol penjelasan tentang Tahlil Dan Do'a.

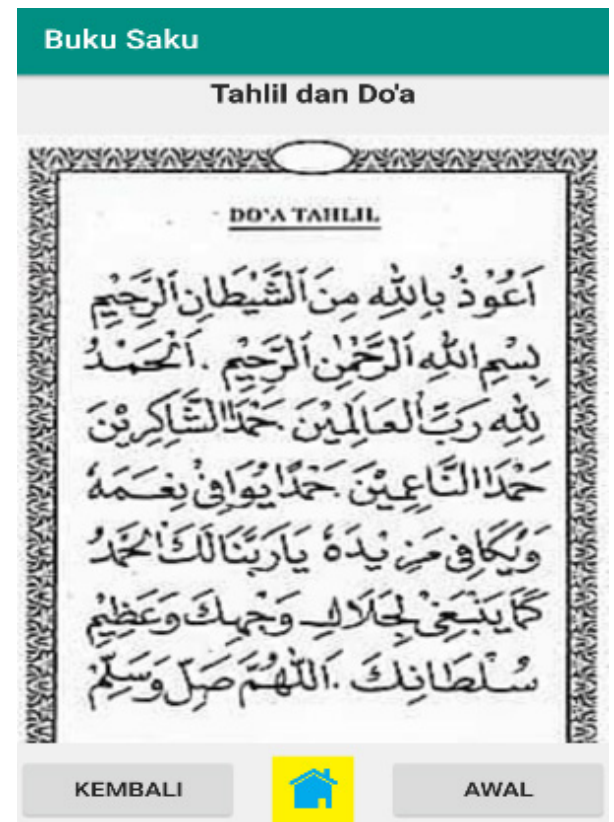

Gambar 2.16 Tampilan Halaman Tahlil Dan Do'a

\section{q. Tampilan Halaman Utama ke 2}

Tampilan halaman utama adalah tampilan yang akan muncul jika keluar menu Pada tampilan ini terdapat 9 tombol diantaranya sunan ampel, sunan gresik, sunan bonang, sunan drajat, sunan giri, sunan muria, sunan kudus, sunan kalijaga, sunan gunungjati.

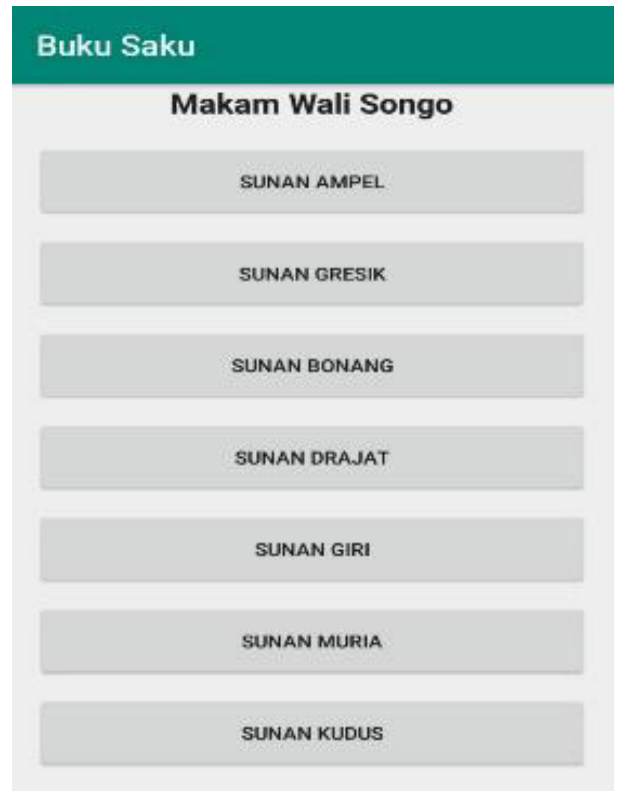




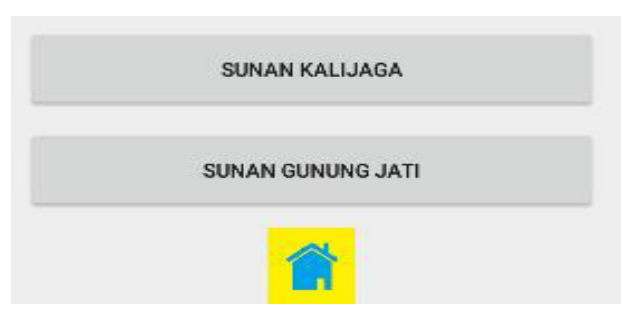

Gambar 2.17 Tampilan Halaman Utama ke 2

\section{r. Tampilan Halaman lokasi wali songo}

Tampilan halaman Lokasi Wali Songo merupakan tampilan yang digunakan untuk tampilan Lokasi Wali Songo. Pada tampilan Lokasi Wali songo terdapat 1 tombol penjelasan tentang Lokasi Wali Songo.

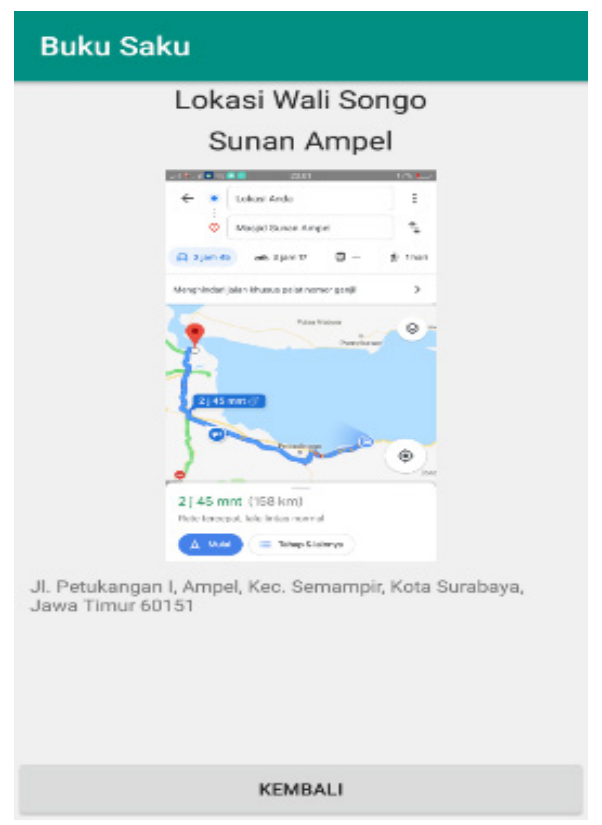

Gambar 2.18 Tampilan Halaman lokasi wali songo1

\section{s. Tampilan Halaman lokasi wali songo}

Tampilan halaman Lokasi Wali Songo merupakan tampilan yang digunakan untuk tampilan Lokasi Wali Songo. Pada tampilan Lokasi Wali songo terdapat 1 tombol penjelasan tentang Lokasi Wali Songo.

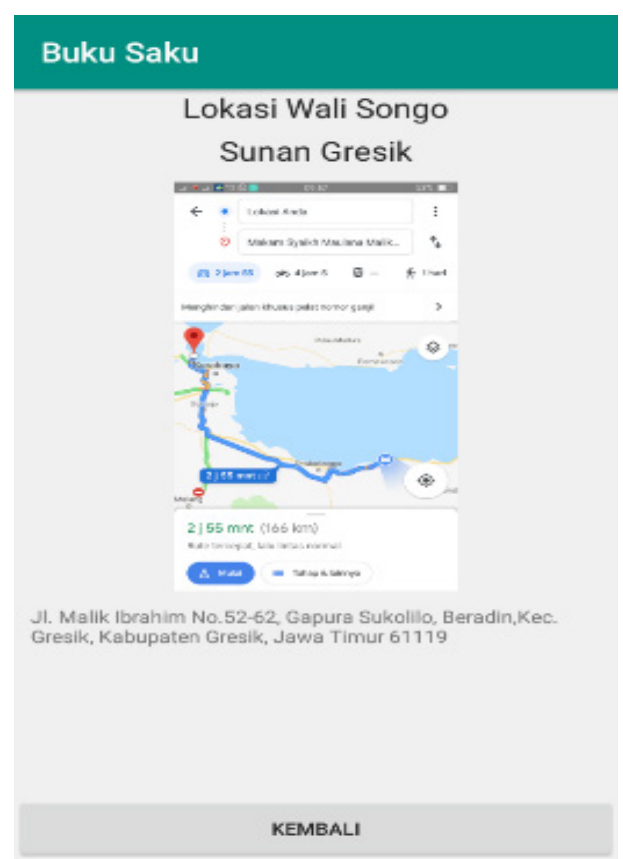

Gambar 2.19 Tampilan Halaman lokasi wali songo2

\section{t. Tampilan Halaman lokasi wali songo}

Tampilan halaman Lokasi Wali Songo merupakan tampilan yang digunakan untuk tampilan Lokasi Wali Songo. Pada tampilan Lokasi Wali songo terdapat 1 tombol penjelasan tentang Lokasi Wali Songo.

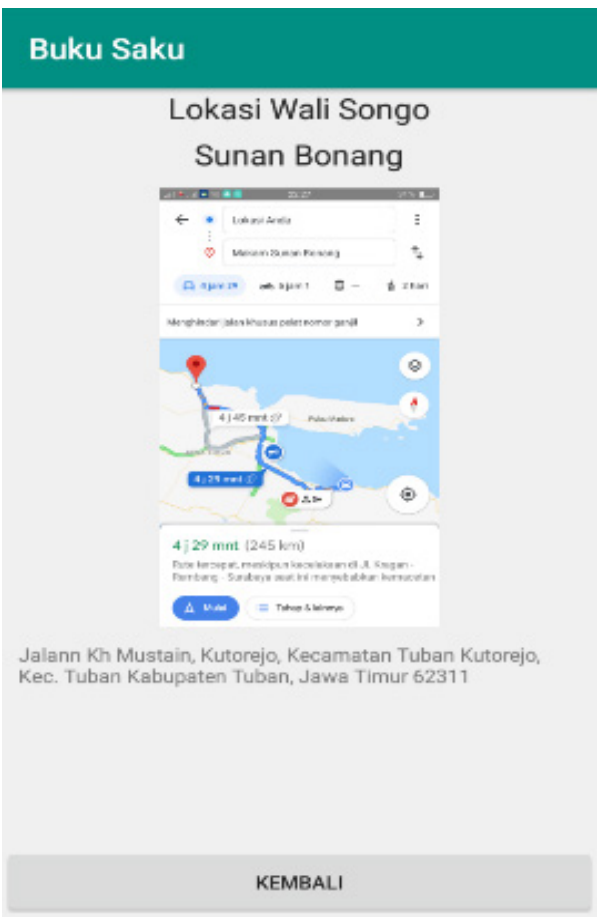

Gambar 2.20 Tampilan Halaman lokasi wali songo3 


\section{u. Tampilan Halaman lokasi wali songo}

Tampilan halaman Lokasi Wali Songo merupakan tampilan yang digunakan untuk tampilan Lokasi Wali Songo. Pada tampilan Lokasi Wali songo terdapat 1 tombol penjelasan tentang Lokasi Wali Songo.

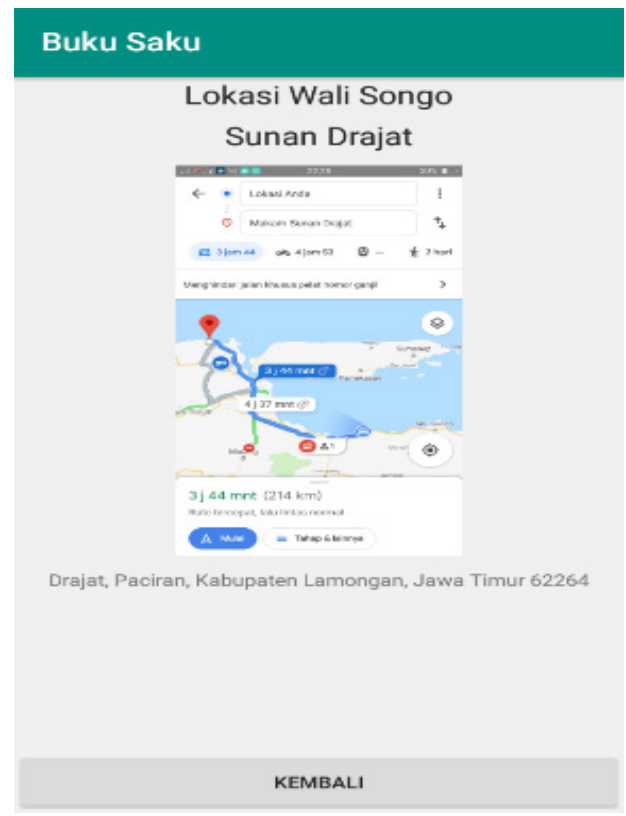

Gambar 2.21 Tampilan Halaman lokasi wali songo4

\section{v. Tampilan Halaman lokasi wali songo}

Tampilan halaman Lokasi Wali Songo merupakan tampilan yang digunakan untuk tampilan Lokasi Wali Songo. Pada tampilan Lokasi Wali songo terdapat 1 tombol penjelasan tentang Lokasi Wali Songo.

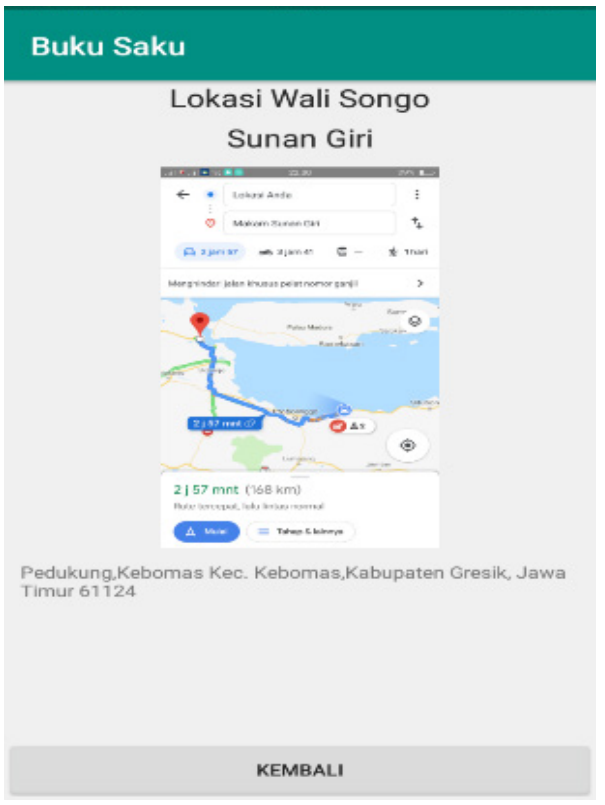

Gambar 2.22 Tampilan Halaman lokasi wali songo5

\section{w. Tampilan Halaman lokasi wali songo}

Tampilan halaman Lokasi Wali Songo merupakan tampilan yang digunakan untuk tampilan Lokasi Wali Songo. Pada tampilan Lokasi Wali songo terdapat 1 tombol penjelasan tentang Lokasi Wali Songo.

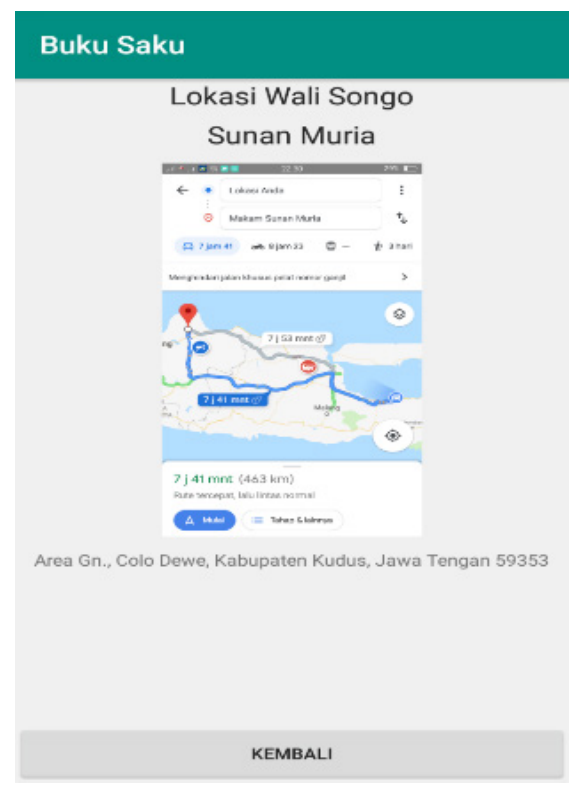

Gambar 2.23 Tampilan Halaman lokasi wali songo6

\section{x. Tampilan Halaman lokasi wali songo}

Tampilan halaman Lokasi Wali Songo merupakan tampilan yang digunakan untuk tampilan Lokasi Wali Songo. Pada tampilan Lokasi Wali songo terdapat 1 tombol penjelasan tentang Lokasi Wali Songo.

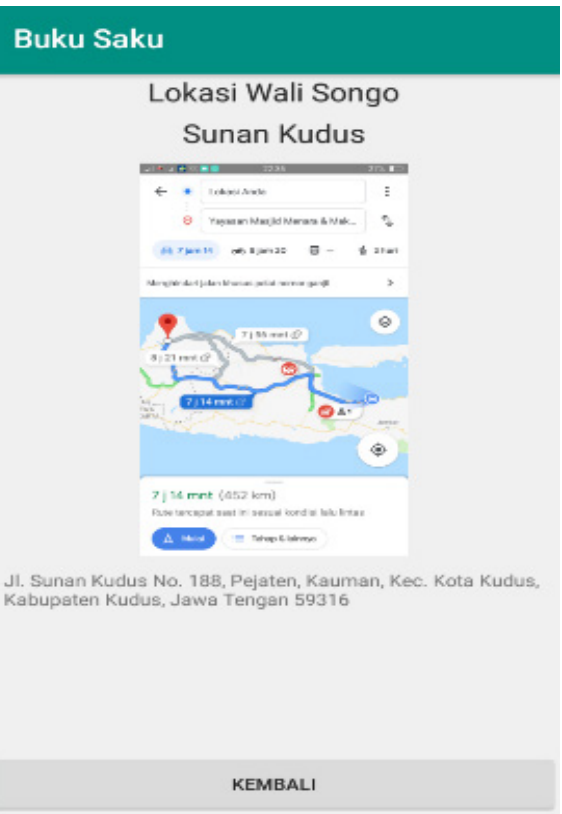

Gambar 2.24 Tampilan Halaman lokasi wali songo7 


\section{y. Tampilan Halaman lokasi wali songo}

Tampilan halaman Lokasi Wali Songo merupakan tampilan yang digunakan untuk tampilan Lokasi Wali Songo. Pada tampilan Lokasi Wali songo terdapat 1 tombol penjelasan tentang Lokasi Wali Songo.

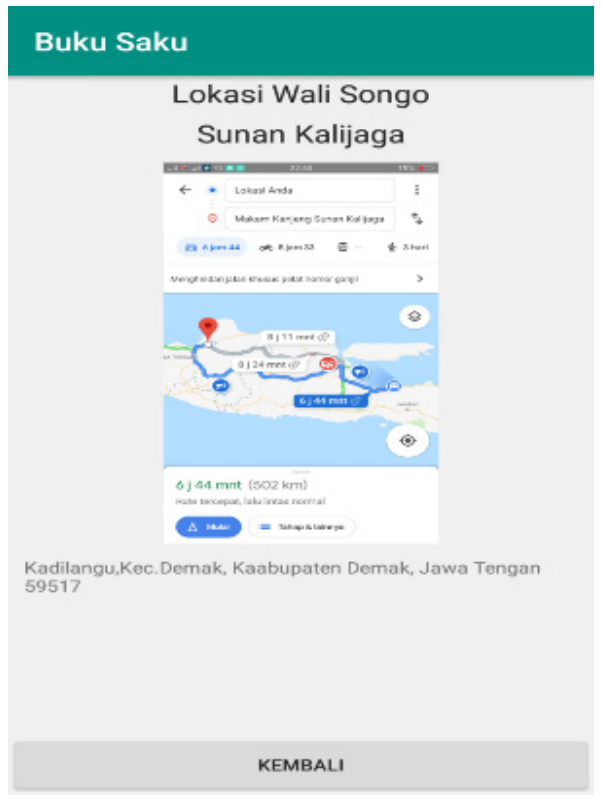

Gambar 2.25 Tampilan Halaman lokasi wali songo8

\section{z. Tampilan Halaman lokasi wali songo}

Tampilan halaman Lokasi Wali Songo merupakan tampilan yang digunakan untuk tampilan Lokasi Wali Songo. Pada tampilan Lokasi Wali songo terdapat 1 tombol penjelasan tentang Lokasi Wali Songo.

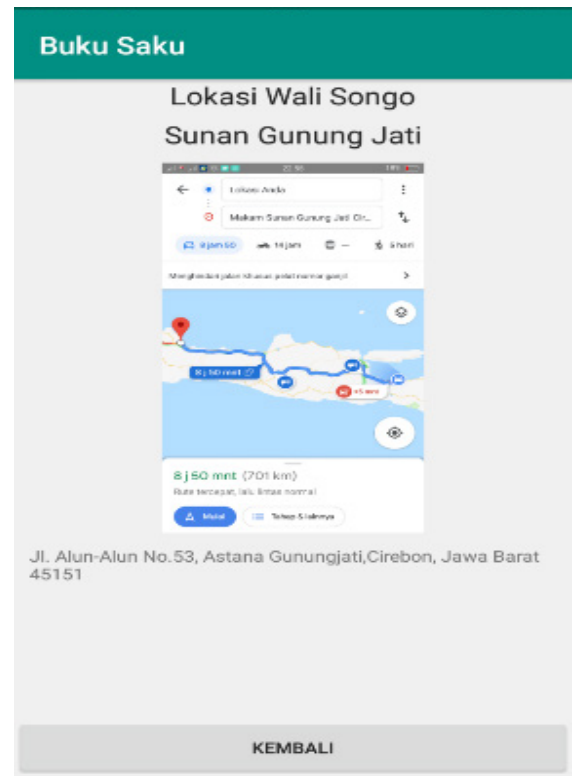

Gambar 2.26 Tampilan Halaman lokasi wali songo9

\section{B. Revisi Produk}

Setelah melewati implementasi dilakukan uji coba untuk mendapatkan revisi produk dilkukan beberapa pengujian yang dilakukan oleh dosen ahli, Pimpinan di lapangan dan Zunio Tour Karang Anyar Paiton Probolinggo.

\section{a. Data Hasil Pengujian White Box}

Dalam pengujian ini dipilih dosen Teknik Informatika yakni Bapak Moh. Jasri, M.Kom. selaku Wakil Dekan di Universitas Nurul Jadid. Berikut adalah data yang diperoleh dari hasil pengujian

Tabel 3.1 Hasil Validasi Pengujian White Box

\begin{tabular}{|c|c|c|c|c|c|c|}
\hline \multirow[t]{2}{*}{ No. } & \multirow{2}{*}{$\begin{array}{l}\text { Fungsi } \\
\text { yang } \\
\text { diuji }\end{array}$} & \multirow{2}{*}{$\begin{array}{l}\text { Fungsi } \\
\text { Tombol }\end{array}$} & \multicolumn{2}{|c|}{$\begin{array}{l}\text { Hasil } \\
\text { Tombol }\end{array}$} & \multicolumn{2}{|c|}{$\begin{array}{l}\text { Hasil } \\
\text { Koding }\end{array}$} \\
\hline & & & Baik & Tidak & Baik & Tidak \\
\hline 1 & $\begin{array}{l}\text { Tombol } \\
\text { dan } \\
\text { Koding } \\
\text { gambar } \\
\text { dan } \\
\text { Sejarah }\end{array}$ & $\begin{array}{l}\text { Untuk } \\
\text { menampilkan } \\
\text { gambar dan } \\
\text { Sejarah } \\
\text { tentang } \\
\text { ziarah wali } \\
\text { songo } \\
\end{array}$ & $\sqrt{ }$ & & $\sqrt{ }$ & \\
\hline 2 & $\begin{array}{l}\text { Tombol } \\
\text { dan } \\
\text { Koding } \\
\text { berbasis } \\
\text { android }\end{array}$ & $\begin{array}{l}\text { Untuk } \\
\text { melakukan } \\
\text { dan } \\
\text { menampilkan } \\
\text { gambar dan } \\
\text { Sejarah }\end{array}$ & $\sqrt{ }$ & & $\sqrt{ }$ & \\
\hline 3 & $\begin{array}{l}\text { Tombol } \\
\text { dan } \\
\text { Koding } \\
\text { sejarah }\end{array}$ & $\begin{array}{l}\text { Menampilkan } \\
\text { gambar dan } \\
\text { Sejarah } \\
\text { yang } \\
\text { ditampilkan }\end{array}$ & $\sqrt{ }$ & & $\sqrt{ }$ & \\
\hline 4 & $\begin{array}{l}\text { Tombol } \\
\text { dan } \\
\text { Koding } \\
\text { Tentang } \\
\text { Sejarah }\end{array}$ & $\begin{array}{l}\text { Menampilkan } \\
\text { informasi } \\
\text { tentang } \\
\text { aplikasi }\end{array}$ & $\sqrt{ }$ & & $\sqrt{ }$ & \\
\hline 5 & $\begin{array}{l}\text { Tombol } \\
\text { dan } \\
\text { koding } \\
\text { Keluar }\end{array}$ & $\begin{array}{l}\text { Tombol } \\
\text { untuk keluar } \\
\text { dari aplikasi }\end{array}$ & $\sqrt{ }$ & & $\sqrt{ }$ & \\
\hline
\end{tabular}

b. Data H asil Pengujian Internal (Black Box)

Dalam pengujian Black Box digunakan untuk menguji fungsi-fungsi khusus dari perangkat lunak yang dirancang. Dalam pengujian ini dipilih Pimpinan Zunio tour yakni Syaifuddin Zuhri, S.Kom selaku Pimpinan Travel Karang Anyar Paiton Probolinggo. 
Tabel 3.2 Hasil Validasi Pengujian Black Box

\begin{tabular}{|l|l|l|l|l|}
\hline \multirow{2}{*}{ No. } & \multirow{2}{*}{$\begin{array}{l}\text { Tombol } \\
\text { yang diuji }\end{array}$} & Fungsi Tombol & \multicolumn{2}{|l|}{ Hasil } \\
\cline { 3 - 5 } 1 & $\begin{array}{l}\text { Tombol } \\
\text { Sejarah }\end{array}$ & $\begin{array}{l}\text { Dapat } \\
\text { menampilkan } \\
\text { Sejarah }\end{array}$ & $V$ & Tidak \\
\hline 2 & $\begin{array}{l}\text { Tombol Surat } \\
\text { Yasin }\end{array}$ & $\begin{array}{l}\text { Dapat } \\
\text { menampilkan } \\
\text { Bacaan }\end{array}$ & $V$ & \\
\hline 3 & $\begin{array}{l}\text { Tombol Tahlil } \\
\text { Dan Do'a }\end{array}$ & $\begin{array}{l}\text { Dapat } \\
\text { menampilkan } \\
\text { Bacaan }\end{array}$ & $\sqrt{ }$ & \\
\hline 4 & $\begin{array}{l}\text { Tombol } \\
\text { Lokasi Wali } \\
\text { Songo }\end{array}$ & $\begin{array}{l}\text { Dapat } \\
\text { menampilkan } \\
\text { Lokasi Wali songo }\end{array}$ & $\sqrt{ }$ & \\
\hline 5 & $\begin{array}{l}\text { Tombol } \\
\text { Keluar }\end{array}$ & $\begin{array}{l}\text { Tombol Untuk } \\
\text { Keluar Dari Aplikasi }\end{array}$ & $\sqrt{ }$ & \\
\hline
\end{tabular}

\section{c. Data Hasil Pengujian Eksternal (User)}

Hasil pengujian oleh pengguna dilakukan oleh 10 orang atau pengguna dan dapatkan hasil pada tabel 3.3

Tabel 3.3. Hasil Validasi Pengujian Eksternal (User)

\begin{tabular}{|c|c|c|c|c|c|}
\hline \multirow[b]{2}{*}{ No } & \multirow[b]{2}{*}{ Pertanyaaan } & \multicolumn{4}{|c|}{ Jawaban } \\
\hline & & $\begin{array}{l}\text { Sangat } \\
\text { Setuju }\end{array}$ & Setuju & \begin{tabular}{|c|} 
Kurang \\
Setuju
\end{tabular} & $\begin{array}{l}\text { Tidak } \\
\text { Setuju }\end{array}$ \\
\hline 1 & $\begin{array}{l}\text { Aplikasi ini } \\
\text { membantu } \\
\text { user lebih } \\
\text { efektif dalam } \\
\text { memahami buku } \\
\text { saku ziarah. }\end{array}$ & 4 & 5 & 1 & \\
\hline 2 & $\begin{array}{l}\text { Aplikasi ini } \\
\text { sangant } \\
\text { bermanfaat } \\
\text { sebagai buku } \\
\text { saku ziarah. }\end{array}$ & 4 & 5 & 1 & \\
\hline 3 & $\begin{array}{l}\text { Aplikasi mudah } \\
\text { digunakan. }\end{array}$ & 3 & 5 & 2 & \\
\hline 4 & \begin{tabular}{|l}
$\begin{array}{l}\text { Aplikasi Praktis } \\
\text { digunakan. }\end{array}$ \\
\end{tabular} & 4 & 4 & 2 & \\
\hline 5 & $\begin{array}{l}\text { Aplikasi } \\
\text { ini mudah } \\
\text { dipahami. }\end{array}$ & 4 & 6 & & \\
\hline 6 & $\begin{array}{l}\text { Tidak ada } \\
\text { kesulitan dalam } \\
\text { menggunakan } \\
\text { aplikasi ini }\end{array}$ & 4 & 6 & & \\
\hline
\end{tabular}

\begin{tabular}{|c|c|c|c|c|c|}
\hline 7 & $\begin{array}{l}\text { User dapat } \\
\text { menggunakan } \\
\text { aplikasi ini } \\
\text { dengan benar } \\
\text { setiap saat user } \\
\text { menggunakan- } \\
\text { nya. }\end{array}$ & 2 & 7 & 1 & \\
\hline 8 & $\begin{array}{l}\text { User dapat } \\
\text { menggunakan } \\
\text { aplikasi ini } \\
\text { dengan benar } \\
\text { setiap saat user } \\
\text { menggunakan- } \\
\text { nya. }\end{array}$ & 5 & 5 & & \\
\hline 9 & $\begin{array}{l}\text { User puas } \\
\text { dengan aplikasi } \\
\text { ini. }\end{array}$ & 3 & 6 & 1 & \\
\hline 10 & \begin{tabular}{|l} 
Aplikasi ini \\
nyaman untuk \\
digunakan
\end{tabular} & 3 & 6 & 1 & \\
\hline 11 & $\begin{array}{l}\text { Aplikasi ini } \\
\text { bekerja seperti } \\
\text { yang user } \\
\text { inginkan }\end{array}$ & 6 & 4 & & \\
\hline \multicolumn{2}{|c|}{ Jumlah Total } & 42 & 59 & 9 & 10 \\
\hline
\end{tabular}

Berdasarkan pengumpulan hasil responden diatas, maka dapat ditentukan skor sebagai berikut:

Tabel 4.4 Keterangan Skor dengan Skala Likert

\begin{tabular}{|l|l|}
\hline Skor & Interpretasi \\
\hline 1 & Tidak Setuju \\
\hline 2 & Kurang Setuju \\
\hline 3 & Setuju \\
\hline 4 & Sangat Setuju \\
\hline
\end{tabular}

Perolehan skor $=\Sigma$ skor responden

a) Skor hasil pengumpulan data

$=(42 \times 4)+(59 \times 3)+(9 \times 2)+(0 \times 1)$

$=168+177+18+0$

$=363$

b) Jumlah Skor Ideal $4 \times 11 \times 10=440$

Tabel 3.5 Keterangan Atas Kategori Dari Skor Jawaban Responden

\begin{tabular}{|l|l|}
\hline Skor Persentasi & Interpretasi \\
\hline $0-21 \%$ & Tidak Setuju \\
\hline $26-50 \%$ & Kurang Setuju \\
\hline $51-75 \%$ & Setuju \\
\hline $76-100 \%$ & Sangat Setuju \\
\hline
\end{tabular}


Rumus Penentuan Skor $=($ Skor Perolehan $/$ Skor Ideal) $\times 100$.

Perhitungan $(363 / 440) \times 100=82,5$ hasil perhitungan mengunakan metode skala likert didapatkan data sebanyak $82 \%$ yang artinya Aplikasi Buku Elektronik Ziarah Wali Songo Berbasis Android ini Sangat Setuju dan layak untuk digunakan sebagai pengganti buku elektronik walisongo

\section{Simpulan}

Berdasarkan uraian pada bab pendahuluan, bab studi pustaka, bab kerangka teoritik \& pengambangan dan bab hasil, maka dapat diambil suatu kesimpulan yaitu menghasilkan Aplikasi Buku Elektronik Ziarah Wali Songo Berbasis Mobile Computing. Aplikasi yang dihasilkan dapat membantu zunio tour, pada umumnya dalam Dengan menggunakan berbasis android, zunio tuor dapat melihat langsung di buku elektronik ziarah wali songo dengan menggunakan Android.

\section{Daftar Pustaka}

Achmad ainul yaqin, A. R. (2017). IMPLEMENTASI METODE TERM FREQUENCY INVERSED DOCUMENT FREQUENCE (TF-IDF) DAN VECTOR SPACE MODEL PADA APLIKASI PEMBERKASAN SKRIPSI BERBASIS WEB. Vol. 9 No. $1,1-5$.

Astrid A. A. Makiolor, A. A. (2017). Rancang Bangun Pencarian Rumah Sakit, Puskesmas dan Dokter Praktek Terdekat di Wilayah Manado Berbasis Android. Vol 10, No.1, 1-10.

Bungin, B. (2015). Analisis Data Penelitian Kualitatif. Jakarta: PT. Raja Grafindo Persada Ciputra,. Volume 2, Nomor 2, , 1-8.

Harni Kusniyati, N. S. (2016). APLIKASI EDUKASI BUDAYA TOBA SAMOSIR BERBASIS ANDROID. VOL. 9 NO. 1, , 1-10.

Juansyah, A. (2015). PEMBANGUNAN APLIKASI CHILD TRACKER BERBASIS ASSISTED GLOBAL POSITIONING SYSTEM (A-GPS) DENGAN PLATFORM ANDROIDJuansyah. Edisi. 1 Volume. $1,1-8$.
Kholid, A. I. (2016). WALI SONGO: EKSISTENSI DAN PERANNYA DALAM ISLAMISASI DAN IMPLIKASINYA TERHADAP MUNCULNYA TRADISI-TRADISI DI TANAH JAWA. TAMADDUN Vol. 4 Edisi 1, 1-6.

M. Haris Qamaruzzaman, F. H. (2016). APLIKASI MOBILE PERPUSTAKAAN BERBASIS ANDROID. Vol. 6, No. 1, , 1-12.

Mania, S. (2008). Observasi Sebagai Alat Evaluasi Dalam Dunia Pendidikan Dan Pengajaran. VOL. 11 NO. 2 , 1-14.

Miftahul Khoiri, M. W. (2017). SISTEM INFORMASI GEOGRAFIS WALI SONGO BERBASIS ANDROID. J-TIIES Vol. 1 No.1, 1-14.

Mulia Rahmayu \& Rosi Kusuma Serli. (2018). PERANCANGAN MEDIA PEMBELAJARAN PENGENALAN TOKOH DAN PENINGGALAN SEJARAH WALISONGO PADA SDS AULIA. JUSIM, Vol 3 No.1, 1-9.

Nisa, K. (2016). GAME EDUKASI MENGENAL SEJARAH ISLAM PADA MASA WALISONGO BERBASIS MULTI PLATFORM. SURAKARTA: FAKULTAS KOMUNIKASI DAN INFORMATIKA UNIVERSITAS MUHAMMADIYAH.

Sulihati, A. (2016). APLIKASI AKADEMIK ONLINE BERBASIS MOBILE ANDROID PADA UNIVERSITAS TAMA JAGAKARSA. Volume $X I$, Nomor 1 , 7-8.

Sultoni. (2016). NILAI-NILAI AJARAN TASAWUF WALISONGO, DAN PERKEMBANGANNYA DI NUSANTARA. Vol. 1 No. 2 , 1-4.

Sunarni, W. (2018). NILAI-NILAI PENDIDIKAN ISLAM DALAM ZIARAH KUBUR DI MAKAM JAKA TINGKIR DESA GEDONGAN KECAMATAN PLUPUH KABUPATEN SRAGEN. SURAKARTA: FAKULTAS ILMU TARBIYAH DAN KEGURUAN IAIN.

Supriyadi, S. \&. (2015). Rancang Bangun Sistem Informasi Praktek Kerja Lapangan Berbasis Web dengan Metode Waterfall. Vol.7 No.1 , 1-6.

Windiarti, E. (2016). PENGEMBANGAN BUKU SAKU PENGOLAHAN SEREALIA DAN KACANG-KACANGAN (DODOL, DONAT, SUSU KEDELAI) UNTUK SISWA SMK KELAS XII TEKNOLOGI PENGOLAHAN HASIL PERTANIAN (TPHP). YOGYAKARTA: FAKULTAS TEKNIK UNIVERSITAS NEGERI. 